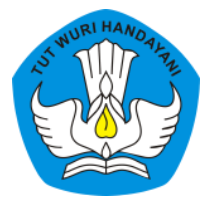

Page: $737-756$

\title{
PENGEMBANGAN MEDIA KOMIK DIGITAL BERBASIS STEM UNTUK MENINGKATKAN LITERASI SAINS SISWA SEKOLAH DASAR
}

\author{
Tri Handayani \\ Sekolah Dasar Negeri 7 Rejang Lebong, Bengkulu, Indonesia \\ Contributor Email: trihandayanitambrin@gmail.com
}

Received: Feb 15, 2021

Accepted: Jul 2, 2021

Published: Nov 30, 2021

Article Url: https://ojsdikdas.kemdikbud.go.id/index.php/didaktika/article/view/343

\begin{abstract}
The low motivation of students in increasing scientific literacy is evidenced by the low learning outcomes of grade VI students. This study aims to develop STEM-based digital comic media to improve students' scientific literacy skills, especially the dimensions of process, content, and context. This type of research is $4 D$ research and development (Research \& Development) through a descriptive approach. The development stages are Define, Design, Development, and Disseminate. Research during this pandemic was only carried out up to 3 stages of development. This research was validated by competent experts and teachers. Validation aspects include aspects of material feasibility, linguistic feasibility, and graphic feasibility. In terms of practicality, this media development uses 20 student responses and 1 teacher response. The use of tests in this study was only carried out to determine the cognitive improvement of students. Based on the validation results by 2 material experts, 2 media experts, and 2 graphic experts developing STEMbased digital comic media, the average score is 3.24 , very feasible category with little input. The development of STEM-based digital comic media to improve student literacy skills in the dimensions of process, content, and context, it can be concluded that, for the three dimensional aspects, the average response is $97.85 \%$, so that STEM-based digital comic media is categorized as very practical and the media is very feasible and practical. used for learning.
\end{abstract}

Keywords: Digital Comics; STEM; Media; Scientific Literacy. 


\begin{abstract}
Abstrak
Rendahnya motivasi siswa dalam meningkatkan literasi sains terbukti dengan rendahnya hasil belajar pada siswa kelas VI. Penelitian ini bertujuan untuk mengembangkan media komik digital berbasis STEM untuk meningkatkan kemampuan literasi sains siswa khususnya dimensi proses, konten, dan konteks. Jenis penelitian yang digunakan adalah penelitian dan pengembangan (Research E Development) 4D melalui pendekatan deskriptif. Tahap pengembangan yaitu Define, Design, Development, dan Disseminate. Penelitian di masa pandemi ini hanya dilakukan hingga 3 tahap pengembangan. Penelitian ini divalidasi oleh ahli dan guru yang berkompeten. Aspek validasi meliputi aspek kelayakan materi, kelayakan kebahasaan, dan kelayakan kegrafikan. Dari segi kepraktisan pengembangan media ini menggunakan respon 20 siswa dan respon 1 guru. Penggunaan tes pada penelitian ini hanya dilakukan untuk mengetahui peningkatan kognitif siswa. Berdasarkan hasil validasi oleh 2 ahli materi, 2 ahli media, dan 2 ahli kegrafisan pengembangan media komik digital berbasis STEM diperoleh rata-rata skor 3,24 kategori sangat layak dengan sedikit masukan. Pengembangan media komik digital berbasis STEM untuk meningkatkan kemampuan literasi siswa dimensi proses, konten, dan konteks disimpulkan bahwa, ketiga aspek dimensi diperoleh hasil rata-rata respon 97,85\%, sehingga media komik digital berbasis STEM dikategorikan sangat praktis dan media sangat layak dan praktis digunakan untuk pembelajaran.
\end{abstract}

Kata Kunci: Komik Digital; STEM; Media; Literasi Sains.

\title{
A. Pendahuluan
}

Perkembangan dunia yang begitu pesat telah memberikan pengaruh besar pada perkembangan pendidikan. Saat ini, Indonesia harus siap menjalankan pendidikan abad 21 yang terfokus pada kemampuan peserta didik dalam berpikir kritis, kreatif, bekerjasama, dan kemampuan dalam berkomunikasi. Pada jenjang pendidikan sekolah dasar, pendidikan abad 21 telah diimplementasikan dalam Kurikulum 2013 melalui pengintegrasian beberapa mata pelajaran dan juga pengembangan karakter. Pengintegrasian mata pelajaran dijenjang Sekolah Dasar (SD) diterapkan pada mata pelajaran tematik. Salah satu pelajaran yang diintegrasikan dalam pelajaran tematik adalah Ilmu Pengetahuan Alam (IPA).

Pembelajaran melalui literasi sains yaitu pembelajaran yang sesuai dengan hakikat pembelajaran IPA yang menekankan pada pengetahuan, proses dan sikap ilmiah. Penilaian dalam literasi sains ditujukan pada pemahaman peserta didik terhadap konten, proses dan aplikasi sains (Yuliati, 2017). Kemampuan literasi sains membantu peserta didik untuk mengkaitkan konten pengetahuan sains dan teknologi terhadap fenomena alam melalui 
aplikasi sains. Untuk dapat mengoptimalkan kemampuan literasi sains peserta didik, perlu ketepatan dalam memilih pendekatan belajar.

Pendekatan pembelajaran berbasis STEM (Science, Technology, Engineering, dan Math) merupakan pendekatan belajar yang memberikan dampak positif pada pengembangan literasi sains. Karena secara umum, pembelajaran berbasis STEM mendorong peserta didik untuk mendesain, mengembangkan, memanfaatkan, dan mengaplikasikan sains dan teknologi.

Berdasarkan analisis buku siswa Pokarindo tema 9 mengenai "Menjelajah Angkasa Luar" terhadap literasi sains dan subjek STEM diperoleh bahwa untuk analisis produk, 55\% menyajikan fakta, $18 \%$ menyajikan konsep, 9\% menyajikan prinsip dan $18 \%$ menyajikan model, 30\% menyajikan rencana eksperimen, 30\% menyajikan interprestasi data, $20 \%$ menyajikan penyusunan kesimpulan, dan 20\% menyajikan mengkomunikasikan hasil kerja.

Keberadaan subjek STEM pada buku siswa Pokarindo sudah mencakup sains, teknologi, dan enjinering. Untuk komponen matematika masih terdapat keterkaitan buku siswa dengan tema 9 Menjelajah Tata Surya dengan buku kelas 4 matematika oleh penerbit platinum pada KD 3.3. Analisis buku ajar menunjukkan bahwa kesiapan pembelajaran literasi sains dan pendekatan STEM telah tercakup di buku materi ajar. Oleh sebab itu guru sebagai fasilitator pembelajaran dituntut untuk mendesain dan melaksanakan pembelajaran pada literasi sains dan pendekatan STEM.

Hasil wawancara dengan guru kelas mengenai literasi sains dan STEM di Sekolah Dasar Negeri 2 Rejang Lebong menunjukkan bahwa (a) Guru masih mengalami kesulitan dalam meningkatkan literasi sains siswa dan guru belum mengenal istilah STEM. (b) Kesulitan siswa meningkatkan literasi sains siswa karena kurangnya minat siswa kurang untuk mempelajari materi yang ada pada buku siswa. Salah satu penyebab kurang optimalnya guru menerapkan literasi sains dan pendekatan STEM adalah media yang digunakan belum bervariasi. Misalnya gambar dan buku siswa kurang menarik karena gambar dalam ilustrasi tersebut tidak bergerak. Untuk melaksanakan pembelajaran yang menarik perhatian siswa diperlukan kreativitas guru dalam mengembangkan media belajar yang kreatif. 
Dengan perkembangan teknologi saat ini pengembangan media komik dapat diintegrasikan melalui teknologi digital. Hal ini menjadi lebih baik, karena peserta didik akan lebih mudah mengakses media komik digital dari pada media komik berbentuk hardcopy.

Komik digital juga lebih murah pembuatannya dari pada komik cetak. Pengembangan komik digital telah dilakukan oleh beberapa peneliti untuk digunakan sebagai media belajar. Pada mata pelajaran bahasa Indonesia tema "lingkungan sahabat kita" kelas 5 SD, media komik digital memiliki pengaruh yang signifikan, namun kekurangannya jika menggunakan komik digital yang sudah ada banyak gaya bahasa yang kurang baik dan beberapa cerita yang menonjolkan kekerasan (Kustianingsari, 2015). Berdasarkan penelitian pengembangan yang dilakukan oleh peneliti sebelumnya, maka potensi penelitian pengembangan media komik digital untuk materi IPA kelas VI SD masih relevan dilakukan terutama untuk tema 9 mengenai "Menjelajah Angkasa Luar".

Penelitian ini juga akan mengintegarsikan literasi sains dan pendekatan STEM pada pengemabangan komik digital. Berdasarkan latar belakang masalah yang telah diutarakan sebelumnya, maka identifikasi masalah pada penelitian ini adalah; (1) Literasi sains merupakan salah satu pembelajaran yang menekankan pada pengetahuan, proses, dan sikap ilmiah. Pemahaman literasi sains juga ditekankan pada kemampuan konten, proses, dan konteks. Untuk mengoptimalkan kemampuan literasi sains siswa perlu ketepatan dalam memilih media belajar. PISA mengambil sampel konsep-konsep sains untuk mewakili penilaian konten sains, adapun tema-tema utama yang menjadi acuan, yaitu : (a) struktur dan sifat materi; (b) bumi dan alam semesta.

(2) Data yang diperoleh dari analisis buku siswa menunjukkan tidak seimbangnya persentase fakta, konsep, prinsip dan penyajian materi. Hal ini mengakibatkan kurangnya minat baca siswa pada pembelajaran sains. (3) Keterkaitan antara pembelajaran IPA dan Matematika belum terarah dan tidak diterapkan pada proses pembelajaran sedangkan terdapat keterkaitan antara pembelajaran IPA dan Matematika pada materi Tata Surya. (4) Guru belum memahami istilah STEM dan kurangnya media pembelajaran sehingga membuat proses pembelajaran terkesan monoton. 
(5) Komik kreatif yang memanfaatkan teknologi seperti penggunaan gambar, suara, animasi merupakan salah satu media yang dapat dijadikan media yang dapat dikembangkan dalam meningkatkan literasi sains berbasi STEM.

Berdasarkan latar belakang, maka permasalahan dalam penelitian ini adalah; (1) Bagaimana mengembangkan komik digital materi IPA tema 9 Kelas VI mengenai “Menjelajah Angkasa Luar”? (2) Bagaimana kelayakan media komik digital jika dilihat dari aspek isi, penyajian dan kegrafikan terhadap literasi sains dan pendekatan STEM materi IPA tema 9 Kelas VI mengenai "Menjelajah Angkasa Luar"? (3) Bagaimana kepraktisan media komik digital terhadap guru dan siswa pada materi IPA tema 9 Kelas VI mengenai "Menjelajah Angkasa Luar"?

\section{B. Metode}

Jenis penelitian yang digunakan adalah penelitian dan pengembangan (Research \& Development) melalui pendekatan deskriptif. Penelitian dan pengembangan merupakan metode penelitian yang berorientasi pada pengembengan suatu produk tertentu dengan tahapan-tahapan dan pengujian kefektifan produk tersebut. Pada penelitian ini akan dikembangkan suatu produk komik digital yang terintegrasi literasi sains dan STEM sebagai media belajar bagi peserta didik di jenjang sekolah dasar. Setelah produk di kembangkan, kemudian diperlukan validasi dan pengujian kepraktisan produk dalam pembejaran IPA pada kelas VI di Sekolah Dasar Negeri 02 Rejang Lebong.

Penelitian ini mengadopsi model pengembangan 4-D yang merupakan proses pengembangan instruksional dengan 4 tahapan yaitu Define (pendefenisian), Design (perancangan), Development (pengem-bangan), dan Disseminate (penyebaran) menurut Pengembangan 4D Menurut Thiagarajan, Semmel (1974). Dalam penelitian ini dilakukan 4 tahapan yaitu pendefenisian, perancangan, pengembangan, dan penyebaran. Dikarenakan masa pandemi, penelitian yang dilakukan hanya 3 tahap pengembangan, Tahap Define (pendefinisian), tahap design (perencanaan), dan tahap develop (pengembangan).

Tahap Pendefenisian (Define) terbagi dalam beberapa tahap yaitu (1) Analisis awal-akhir (pra-post analysis), Analisis ini dilakukan berupa 
penentuan masalah dasar yang dihadapi dalam pembelajaran. Kegiatan yang dilakukan adalah analisis buku ajar, wawancara, dan kuisioner terhadap kegiatan belajar di SDN 2 Rejang Lebong. (2) Analisis peserta didik (learner analysis), Analisis data awal pada penelitian ini menggunakan Kuisioner yang di gunakan pada pengambilan data awal menggunakan google form. Penggunaan google form dilakukan karena saat ini pembelajaraan tatap muka belum berlangsung dikarenakan masih berkembangnya virus covid 19 di seluruh negara termasuk Indonesia dan khususnya di daerah Rejang Lebong Provinsi Bengkulu. Isian angket google form yang digunakan menggunakan identitas bukan angket anonim. Responden yang terlibat dalam pengambilan data awal ini adalah siswa kelas VI tahun ajaran 20192020. Item pertanyaan dalam angket ada 10 butir pertanyaan yang dibuat menggunakan. Link angket isian disebarkan melalui whatshap group. Jenis pertayaan ada yang berupa pilihan jawaban ya atau tidak, pertanyaan yang memerlukan pendapat responden sendiri dan pertanyaan dengan jawaban pilihan lebih dari satu.

(3) Analisis konsep (concept analysis) Analisis konsep dilakukan untuk merinci konsep-konsep pelajaran yang akan dimasukkan kedalam media pembelajaran komik digital. (4) Analisis tugas (task analysis), Analisis tugas bertujuan untuk mengulas tugas yang diberikan setelah penggunaan media komik digital berbasis STEM. Tugas yang diberikan digunakan untuk mengetahui peningkatan literasi sains siswa setelah menggunakan media komik digital. (5) Perumusan tujuan pembelajaran (specifyng instructional objectives), data analisis digunakan sebagai dasar menentukan indikator pencapaian kemampuan literasi sains siswa dan kaitannya dengan pembelajaran matematika serta penggunaan teknologi dalam pembelajaran.

Tahap Perancangan (Design) dibagi beberapa tahap yaitu; (1) Pemilihan tes acuan, Penyusunan tes acuan adalah langkah yang menghubungkan tahap pendefenisian dan tahap perancangan (Mi'rojiyah, 2016). Tes dikembangkan sesuai dengan jenjang kognitif yang disusun melalui kisi-kisi tes belajar. Juga diperlukan rubrik penilaian untuk memberikan skor pada tes. (2) Pemilihan media (media selection) untuk mengidentifikasi media pembelajaran yang relevan dengan karakteristik materi. Dalam hal ini media yang dipilih 
adalah komik digital untuk mengoptimalkan penggunaan media pembelajaran. Komik digital dipilih karena mengandung gambar, warna dan tekstur yang disukai anak serta mengikuti kemajuan zaman. Jalilehvand (2012 : 333) dalam penelitiannya menyatakan gambar memiliki pengaruh terhadap peningkatan kemampuan membaca siswa.

(3) Pemilihan format (format selection), dilakukan untuk mempersiapkan desain yang menarik dan sesuai dengan pemilihan isi pembelajaran. Pemilihan format dilakukan dengan mengadaptasi serta memodifikasi perangkat yang sudah ada dan mengkaji dari komik-komik digital yang sudah ada. Komik digital bertujuan untuk meningkatkan literasi sains siswa dalam meningkatkan kognitifnya terhadap pembelajaran tata surya, sehingga format komik digital harus disesuaikan dengan tujuan tersebut baik dari segi ilustrasi, layout, warna dan isi konten sesuai dengan pernyataan Yonkie A (2017: 126). Rancangan awal (initial design) adalah bentuk rancangan media komik digital yang akan dibuat. Draft rancangan dibuat disesuaikan dengan materi tema 9 mengenai Tata Surya.

Tahap Pengembangan (Development) dilakukan dengan beberapa tahap yaitu; (1) Uji Kevalidan oleh Dosen ahli dan Guru yang berkompeten. (2) Uji kepraktisan. Subjek penelitian ini adalah peserta didik kelas VI pada SDN 2 Rejang Lebong yang berjumlah 22 orang dan guru kelas. Objek penelitian ini adalah komik digital berbasis STEM untuk materi IPA tema 9 Kelas VI mengenai "Menjelajah Angkasa Luar". Pemilihan subjek penelitian menggunakan random sampling. Pemilihan tema berdasarkan analisis buku ajar dengan mencari materi IPA yang sesuai dengan integrasi literasi sains dan pendekatan STEM.

Untuk menghindari kesalahpahaman dan kesamaan konspe dalam mengartikan istilah yang digunakan dalam penelitian pengembangan ini, maka deskripsi beberapa istilah dijelaskan sebagai berikut; (1) Literasi sains dalam penelitian ini adalah literasi sains pada media komik digital yang bersifat kognitivisme dan konstrutivisme dimana peserta didik dapat memperoleh pengetahaun baru melalui proses yang dilakukan sendiri. Selain itu, peserta didik dapat memperoleh pengalaman langsung dalam invetigasi, mengasah kemapuan berpikir, serta dapat menghubungkan 
antara yang dipelajari disekolah dengan lingkungan sekitar sesuai dengan pendapat Rahman (2020) menyatakan untuk meningkatkan literasi sains siswa maka pembelajaran sains harus menyenangkan.

(2) STEM adalah pendekatan yang mengacu pada integrasi sains, teknologi, teknik dan matematika dalam proses belajar. Pada penelitian ini integrasi STEM dilakukan pada media komik digital. (3) Komik digital adalah media belajar berupa cerita bergambar yang disusun untuk menceritakan konsep secara menarik dan mudah dipahami. Komik digital juga merupakan komik yang dipenuhi dengan gambar dan warna yang dibuat menggunakan corel draw. Dalam pengembangannya komik digital menggunakan animasi dan suara.

Teknik pengumpulan data yang digunakan untuk memperoleh data mengenai penelitian pengembangan media komik digital materi mengenai "Menjelajah Angkasa Luar" tema 9 kelas VI sekolah dasar yaitu, analisis buku ajar, wawancara, dan kuisioner. Sugiyono (2015: 222) menyatakan bahwa instrumen dianalogikan sebagai alat penelitian, alat penelitian yang dimaksud adalah peneliti yang sedang melakukan penelitian. Peneliti Kualitatif berfungsi menentapkan apa yang menjadi tujuan dan sasaran penelitian. Sebuah penelitian harus memiliki variabel penelitian. Secara lebih khusus lagi variabel penelitian dapat digunakan untuk mengukur fenomena alam atau fenomena sosial yang diamati. Pada penelitian ini, instrumen yang digunakan yaitu: Rubrik dokumen, Pedoman Wawancara, Lembar Validasi Instrument validasi menggunakan skala 1-4 dengan format ceklist. Instrumen ini memuat 4 aspek pengembangan media pembelajaran yaitu; (1) Aspek materi/ isi, (2) Aspek kebahasaan, (3) Aspek penyajian, (4) Aspek kegrafisan.

Dalam mengambil kesimpulan penelitian ini, langkah-langkah analisa data yang digunakan adalah sebagai berikut; (1) Analisa Validasi Instrumen Oleh Ahli, Penilaian perangkat instrument media komik digital berbasis STEM menggunakan skor dengan rentang 1 sampai 4. Penilaian tersebut menggunakan skala likert. Sugiyono (2013:107) menyatakan skala likert digunakan untuk mengukur pendapat atau persepsi seseorang dalam hal ini pendapat mengenai kualitas bahan ajar yang digunakan.Adapun kriteria penskoran meliputi yaitu sangat baik $=4$, baik $=3$, tidak baik $=2$, 
sangat tidak baik $=1$. Teknik analisis data pada kelayakan yang digunakan untuk media komik digital berbasis STEM ini menurut Mardapi (2008: 123), analisis dapat dilakukan dengan menghitung skor rata-rata dari instrumen-instrumen (2008).

Arifin (2012), mengemukakan bahwa kepraktisan merupakan syarat suatu tes standar. Kepraktisan media komik digital dapat dilihat dari hasil identifikasi angket kepraktisan siswa dan guru. Nilai kepraktisan sebagai berikut; 1) Angket respon siswa diberikan skor untuk setiap item dengan jawaban "ya" atau "tidak".Sedangkan untuk respon guru diberikan skor sangat setuju (4), setuju (3), tidak setuju (2), sangat tidak setuju (1). Pada angket respon siswa terdapat kolom komentar siswa setelah menggunakan media komik digital berbasis STEM. Pemberian nilai kepraktisan dapat dirumuskan sebagai berikut.

Hidayat (2017)

\section{Hasil dan Pembahasan}

\section{Hasil}

\section{a. Hasil Pengembangan Media Pembelajaran}

Penelitian pengembangan ini menghasilkan produk berupa komik digital berbasis STEM untuk meningkatkan kemampuan literasi sains siswa khususnya dimensi proses, konten, dan konteks. Penelitian dilaksanakan bulan Februari 2021. Penelitian dimulai dari instrumen penelitian dan dilanjutkan dengan validasi oleh para ahli.

Pelaksanaan penelitian dilakukaan sesuai dengan pendekatan penelitian dan pengembangan (research and development) yang dikembangkan oleh Thiagarajan, Semmel melalui 4 tahap yaitu perancangan (Design), pengembangan (Development), dan penyebaran (Development). Dalam penelitian masa panemi covid tahap Disseminate tidak memungkinkan untuk dilakukan sehingga penelitian hanya dilakukan 3 tahap pengembangan saja. Data yang dideskripsikan pada bab ini adalah data yang diperoleh pada temuan saat melakukan penelitian dan pengembangan. 


\section{b. Tahap Define (Pendefinisian)}

Hasil analisis awal yang ditemukan terkait masalah pada literasi sains dan integrasinya terhadap pembelajaran matematika pada kurikulum 2013 yang digunakan di Sekolah Dasar Negeri 2 Rejang Lebong. Hasil analisis yang pertama adalah analisis buku siswa tema 9 penerbit Pokarindo. Terkait dengan literasi sains yang akan di analisis ditinjau dari aspek Konten. Hasil analisis buku materi terhadap literasi sains jika dikaitkan dengan silabus yang digunakan dalam buku tematik terpadu Kelas VI Tema 9 Penerbit Viva Pokarindo adalah; (1) Pada sub tema 1 muatan pembelajaran IPA sudah runtun dan sesuai dengan indikator KD 3.7.1 yaitu memahami sistem tata surya dan karakteristik anggota tata surya.

(2) Pada sub tema 2 pengetahuan muatan pembelajaran IPA sudah sesuai dengan fakta yaitu mengenai objek dan peristiwa berputarnya planet pada porosnya serta sudah sesuai dengan indikator KD nya mengenai menjelaskan sistem tata surya dan karakteristik anggota tata surya (bintang). (3) Pada sub tema 3 pengetahuan muatan pembelajaran IPA sudah mengarah kepada prosedur yang melakukan aktivitas pembelajaran menggunakan rumus dan sesuai dengan indikator Kdnya yaitu 3.7.2 Menjelaskan sistem tata surya dan karakteristik anggota tata surya (bintang).

Analisis jurnal diperlukan untuk mengetahui keberhasilan pada penelitian yang relevan dengan komik digital. Beberapa hasil penelitian yang dianalisis sebagai berikut; (1)Penelitian Kustianingsari, N \& Dewi, U. (2018) dengan judul penelitian: Pengembangan Media Komik Digital Pada Mata Pelajaran Bahasa Indonesia Tema Lingkungan Sahabat Kita Materi Teks Cerita Manusia dan Lingkungan Untuk Siswa Kelas V SDN Putat Jaya III/379 Surabaya. Penelitian ini menggunakan media komik dengan ilustrasi gambar yang mewakili materi pembelajaran yang disajikan. (2) Penelitian yang dilakukan oleh Putra,P.D.A. \& Iqbal, M. (2014) dengan judul: Implementation of Digital Comic to Improve Creative Thinking Ability in Integrated Science Study. Penelitian ini merupakan penelitian eksperimen. Penelitian ini juga memuat ilustrasi gambar dan percakapan pada komik digitalnya. (3) Penelitian Winarni, E.W. \& Purwandari, E.P. (2019) dengan judul: The Effectiveness of Turtle Mobile Learning Application for Scientific Literacy in 
Elementary School. Penelitian ini menggunakan aspek pemahaman siswa tentang Penyu Sumatera. Aplikasi ini memiliki efektivitas yang tinggi dalam meningkatkan literasi sains siswa sekolah dasar.

Analisis Siswa dengan pengambilan data awal menggunakan google formulir dengan 10 butir pertanyaan sebagai berikut; (1) berdasarkan data respon yang langsung bisa dilihat persentasenya dan didownload pada bagian tanggapan sebanyak 96,8 \% siswa menjawab iya pada pertanyaan apakah siswa mengetahui pengertian media pembelajaran. (2) Butir pertanyaan ke dua mengenai apakah guru pernah menggunakan media pembelajaran dalam pembelajaran. Pada pertanyaan ini sebanyak $96,8 \%$ menjawab iya, tetapi media seperti komik belum pernah digunakan oleg guru. (3) Pada butir pertanyaan ketiga mengenai apakah buku yang digunakan untuk belajar tata surya di tema 9 menarik untuk dibaca. Pada pertanyaan ini sebanyak 41,9\% siswa menjawab menarik sedangkan $58,1 \%$ siswa menjawab tidak menarik.

(4) Pada butir pertanyaan keempat disajikan beberapa pernyataan yang boleh dipilih lebih dari satu pilihan yang terkait dengan media seperti apa yang dapat meningkatkan motivasi membaca materi IPA. Dari hasil tanggapan, sebanyak $80,6 \%$ siswa menjawab media pembelajaran yang berwana. 93,5 \% siswa juga memilih media yang banyak gambar.(5) Butir pertanyaan kelima disajikan pertanyaan mengenai kesukaan siswa pada komik. Dari pertanyaan tersebut sebanyak 100\% merespon suka komik. Data ini dapat dijadikan alas an kuat untuk membuat media yang berbentuk komik agar bermanfaat pada pembelajaran.

Butir pertanyaan keenam mengenai pendapat siswa mengenai komik. Apa yang menarik dari komik. Beberapa tanggapan siswa yang masuk diantaranya; komik banyak warna dan banyak gambar, menarik karena dibaca menggunakan gambar. (7) Butir pertanyaan ketujuh adalah apakah siswa mengetahui tentang komik digital. Sebanyak $96,8 \%$ siswa menjawab tahu. (9) butir pertanyaan kesembilan adalah apa pendapat siswa jika media pembelajaran yang digunakan pada tema 9 mengenai tata surya dikemas dalam bentuk komik digital. Beberapa respon siswa adalah; sangat seru, ide yang menarik, yang pastinya akan sangat bagus, menarik dan tidak akan bosan untuk dibaca, dan seseorang akan lebih mudah membaca karena 
bisa dibaca menggunakan gawai. Dari data yang diperoleh siswa sangat antusias dan memberikan respon positif terhadap media pembelajaran yang dikemas dalam bentuk komik digital.

\section{c. Tahap Perancangan}

(a) Pemilihan tes acuan, setelah tes pembelajaran dirumuskan, disusun tes acuan sebagai patokan berupa soal pretest dan posttest dalam pembelajaran menggunakan media komik digital berbasis STEM. Tes yang menjadi acuam meliputi dimensi proses, konten, dan konteks. (b) Pemilihan media komik digital dijadikan alternativ pengembangan berdasarkan analisis pada media, dan teknologi yang digunakan pada buku siswa Pokarindo. Pemilihan format dalam pengembangan media pembelajaran komik digital berbasis STEM peneliti Untuk pengaturan gambar, suara, ilustrasi, animasi, dan tata letak komik penulis mengembangkan sendiri. (c) Rancangan Awal komik digital berpedoman pada analisis kebutuhan sebelumnya yaitu analisis kurikulum, analisis buku siswa, analisis siswa, dan analisis subjek STEM yang terdapat dalam buku siswa. Rancangan bahasa komik digital juga disesuaikan dengan karakteristik siswa usia sekolah dasar yang senang dengan pembelajaran konkrit.

\section{d. Tahap Pengembangan}

Pada tahap pengembangan terdapat 2 apek yang diuji yaitu uji kevalidan dan uji kepraktisan. Tes dalam hal ini hanya digunakan untuk mengetahui peningkatan kognitif siswa ditinjau dari pengetahuan. Tahap pengembangan sebagai berikut; (1) Sebelum komik digital berbasis STEM digunakan sebagai media dalam pembelajaran, media komik digital ini harus melalui proses validasi hingga benar-benar dinyatakan layak dan valid. Setiap aspek penilaian divalidasi oleh 2 orang validator. Para validator yang ditunjuk ini adalah ahli dibidangnya.

Kegiatan validasi difokuskan untuk memperbaiki draft komik digital berbasis STEM yang sevelumnya dibuat oleh peneliti. Hasil analisis dari proses validasi adalah media komik digital berbasis STEM layak diujicoba dengan skala terbatas dengan revisi. Hasil validasi kelayakan materi, bahasa, dan kegrafikan dapat dilihat pada tabel berikut. 
Tabel:1 Data Hasil Validasi Secara Keseluruhan

\begin{tabular}{|l|l|l|}
\hline \multicolumn{1}{|c|}{ Validator } & Rerata Skor & \multicolumn{1}{c|}{ Kategori } \\
\hline Ahli Materi & 3,39 & Sangat Layak \\
\hline Ahli Media & 3 & Sangat Layak \\
\hline Ahli Kegrafisan & 3,34 & Sangat Layak \\
\hline Rerata Skor Total & 3,24 & Sangat Layak \\
\hline
\end{tabular}

Dari hasil validasi secara keseluruhan tersebut diketahui bahwa draft media komik digital berbasis STEM yang dibuat oleh peneliti telah memenuhi standar sangat layak, sesuai yang dikemukakan Mardapi (2008) yakni bernilai rata-rata 3,24 secara kualitatif termasuk dalam kategori sangat layak.

\section{e. Uji Kepraktisan}

Produk revisi komik digital yang telah dilakukan berdasarkan validasi ahli diuji kepada guru kelas VI SDN 2 Rejang Lebong dan siswa yang menjadi subjek penelitian yaitu siswa kelas VI SDN 2 Rejang Lebong. Uji kepraktisan dilaksanakan di SDN 2 Rejang Lebong. karena masa pandemi jam pelajaran tidak sesuai dengan masa normal. Begitu juga dengan proses pembelajarannya. Uji kepraktisan media komik digital dilaksanakan pada tanggal 11 Februari 2021. Siswa yang masuk berjumlah 20 orang dengan sistem belajar secara tatap muka terbatas dengan protokol kesehatan. Sebelumnya peneliti telah berkoordinasi dengan wali kelas untuk meminta siswa membawa gawainya ke sekolah untuk digunakan sebagai sumber belajar. Sebelum siswa mengisi lembar respon siswa, peneliti terlebih dahulu mengajar pembelajaran tata surya dengan menggunakan buku siswa dan media komik digital berbasis STEM menggunakan gawai siswa masing-masing. Siswa mengisi lembar respon dengan menjawab ya atau tidak. Selanjutnya di peryataan terakhir siswa diminta untuk menuliskan tanggapan terhadap media komik digital berbasis STEM. Tujuannya adalah untuk mengetahui kepraktisan media pembelajaran yang telah dikembangkan dan hasilnya.

Angket respon siswa terdiri dari 3 aspek penilaian yaitu materi, bahasa, dan kemenarikan. Untuk aspek materi peryataan dari nomor 1 sampai 7. Aspek bahasa untuk peryataan nomor 8 sampai 12, dan pernyataan 
kemenarikan nomor 13 sampai 20. Untuk butir pernyataan pertama 90\% respon positif siswa.

Berikut hasil respon siswa setelah menggunakan media komik digital berbasis STEM.

\begin{tabular}{|c|c|c|c|c|}
\hline No & Aspek & Banyak Butir & Persentase (\%) & Kriteria Persentase \\
\hline 1 & Materi & 7 & 93,57 & Sangat Praktis \\
\hline 2 & Bahasa & 5 & 100 & Sangat Praktis \\
\hline 3 & Penyajian & 8 & 100 & Sangat Praktis \\
\hline \multicolumn{3}{|c|}{ Rerata } & 97,85 & Sangat Praktis \\
\hline
\end{tabular}

Dari data yang diperoleh dapat disimpulkan bahwa penggunaan media komik digital berbasis STEM dikategorikan sangat praktis karena digunakan tanpa kendala yang berarti oleh siswa sesuai dengan pendapat Hidayat (2008).

Hasil uji kepraktisan guru dilakukan dengan guru kelas VI di SDN 2 Rejang Lebong pada tanggal 11 Februari 2021. Pada lembar kepraktisan guru terdapat 10 pertanyaan untuk dijawab guru. Guru menjawab dengan alasan jawaban dan menuliskan angka sesuai dengan kriteria sangat setuju (4); setuju (3); tidak setuju (2); dan sangat tidak setuju (1). Tujuannya adalah untuk mengetahui kepraktisan dari media komik digital berbasis STEM yang telah dibuat. Keseluruhan hasil analisis respon guru dapat dilihat pada tabel berikut.

Tabel: 3 Hasil Analisis Presentase Respon Guru

\begin{tabular}{clcc}
\hline No & \multicolumn{1}{c}{ Aspek } & Persentase & Kriteria Responden \\
1 & Kelayakan Isi & 100 & Sangat Praktis \\
2 & Kelayakan Bahasa & 91,6 & Sangat Praktis \\
3 & Kelayakan & 100 & Sangat Praktis \\
4 & Penyajian & & \\
& Rerata & 97,2 & Sangat Praktis \\
\hline
\end{tabular}

Berdasarkan data tersebut persentase respon guru 97,2\% dengan kategori sangat praktis. 
Pretest dan posttest dilakukan untuk mengetahui peningkatan pengetahuan dalam konten literasi sains. Data pretest diambil setelah siswa membaca buku siswa yang biasa digunakan pada saat pembelajaran. Data posttest diambil setelah menggunakan media komik digital berbasis STEM. Hasil pretest dan post test dapat dilihat pada tabel berikut.

Tabel: 4 Hasil Rekap Pretest dan Posttest

\begin{tabular}{ccc}
\hline Jumlah Siswa & Pretest & Posttest \\
20 siswa & 47,25 & 76,7 \\
\hline
\end{tabular}

Dari hasil Pretest dan posttest terjadi peningkatan nilai pengetahuan siswa. Hal ini membuktikan bahwa penggunaan media komik digital berpengaruh terhadap peningkatan literasi sains siswa.

\section{Pembahasan}

\section{a. Pengembangan Media Komik Digital Berbasis STEM}

Berdasarkan penjelasan hasil penelitian tersebut diperoleh produk berupa media komik digital berbasis STEM untuk kelas VI SD pada materi tata surya. Produk media komik digital ini dikembangkan menggunakan model pengembangan Four-D (4-D) yaitu terdiri dari tahap define, design, develop, dan disseminate tetapi pada masa pandemi ini tahap disseminate tidak dilakukan. Penelitian hanya dilakukan 3 tahap pengembangan saja.

Pada tahap pendefinisian (define) dilakukan analisis awal, analisis peserta didik, analisis konsep, analisis tugas, dan perumusan tujuan pembelajaran. Hasil yang didapat adalah ditemukannya permasalahan yang memerlukan pengembangan media komik digital berbasis STEM. Media yang dikembangkan bisa dibuka menggunakan gawai ataupun PC computer.

Pada tahap perancangan (design) terdapat langkah-langkah yang harus dilewati yaitu pemilihan tes acuan, pemilihan media, pemilihan format, dan rancangan awal. Penyususnan tes acuan mengacu pada pretes dan posttest dari dimensi proses, konten, dan konteks yang akan diukur. Sedangkan langkah pemilihan media berdasarkan analisis konsep dan analisis tugas, karakteristik siswa, dan sarana serta prasarana yang dimiliki oleh siswa, sekolah dan kondisi masa pandemi. 
Tahap pengembangan (develop) bertujuan untuk menghasilkan produk jadi berupa media komik digital berbasis STEM yang telah melalui revisi ahli kelayakan materi, ahli kelayakan bahasa, dan ahli kelayakan media/ kegrafkan. Validasi oleh ahli ini dilakukan untuk mengetahui mana yang sudah menjadi kekuatan media dan mana yang menjadi kelemahan media yang sedang dikembangkan.

\section{b. Kelayakan Media Komik Digital Berbasis STEM}

Hasil kelayakan media komik digital berbasis STEM menunjukkan bahwa media secara keseluruhan sangat layak digunakan dalam pembelajaran. Kelayakan media dibuktikan dari hasil evaluasi dari ahli materi, ahli kebahasaan, dan ahli kegrafikan. Berdasarkan analisis hasil penelitian, diperoleh hasil penilaian sebagai berikut;

a) Ahli Materi

Kelayakan materi pada media komik digital berbasis STEM dibagi menjadi 3 aspek yaitu kesesuaian materi dengan kompetensi inti dan Kompetensi Dasar, keakuratan materi unsur STEM, dan keakuratan materi unsur literasi. Pada lembar validasi aspek materi juga terdapat penilaian kelayakan penyajian. Aspek penyajian dibagi menjadi tiga aspek yaitu teknik penyajian, penyajian pembelajaran, dan keruntutan alur pikir. Media pembelajaran komik digital memperoleh rata-rata 3,39 dari nilai skor maksimal 4. Hal ini membuktikan bahwa ahli materi menyatakan bahwa media komik digital berbasis STEM dalam kategoru "sangat layak" digunakan sebagai media pembelajaran.

Hal ini senada dengan penelitian sebelumnya mengenai pembelajaran STEM menggunakan aplikasi yang dilakukan oleh Sutrisno \& Hamdu (2020) yakni keakuratan materi unsur STEM dapat dibuat dalam aplikasi berbasis android. Pembelajaran komik digital sama halnya dengan penggunaan aplikasi mobile learning dalam pembelajaran. Mobile learning bisa menjadi sumber referensi penyedia perangkat pembelajaran bagi guru dalam melaksanakan model pembelajaran STEM. 
b) Ahli Kebahasaan

Kelayakan kebahasaan pada media komik digital berbasis STEM dibagi menjadi enam aspek penilaian yaitu lugas, komunikatif, dialogis dan interaktif, kesesuaian dengan perkembangan peserta didik, kesesuaian dengan kaidah bahasa, dan alur cerita dalam media komik digital berbasis STEM. Kebahasaan dalam komik digital memperoleh skor 3 dari nilai skor maksimal 4. Hal ini juga membuktikan kebahasaan dalam komik digital berbasis STEM dalam kategori "sangat layak" digunakan pada pembelajaran. Hal ini juga membuktikan kebahasaan dalam komik digital berbasis STEM dalam kategori "sangat layak" digunakan pada pembelajaran sesuai dengan ketentuan yang tertera pada BSNP.

c) Kelayakan media

Kelayakan media/desain pada media komik digital berbasis STEM dibagi menjadi tiga aspek penilaian yang tertuang dalam BSNP yaitu ukuran, desain sampul komik digital, desain isi komik digital dalam media komik digital berbasis STEM. Media/ desain dalam komik digital memperoleh skor 3,34 dari nilai skor maksimal 4 dari warna, tata letak, ukuran huruf, proporsi obyek sesuai dengan realita, dan ilustrasi gambar. Hal ini juga membuktikan media/desain dalam komik digital berbasis STEM dalam kategori "sangat layak".

\section{Penutup}

Berdasarkan hasil penelitian dan pembahasan pengembangan media komik digital berbasis STEM untuk meningkatkan literasi sains dimensi proses, konten, dan konteks siswa sekolah dasar, maka dapat disimpulkan sebagai berikut; (1) Media komik digital berbasis STEM dikembangkan melalui tiga tahapan pengembangan yaitu tahap define, design, dan develop. Pada tahap define terdiri atas analisis awal tentang kurikulum dan silabus, analisis respon siswa terhadap media, analisis materi pada buku siswa tentang unsur STEM dan literasi. Pada tahap design terdiri atas pemetaan konsep/ materi, pemilihan media, pemilihan format, rancangan awal, dan pemilihan tes acuan. Tahap pengembangan melalui uji kevalidan dari aspek 
materi, kebahasaan, kegrafikan dan uji kepraktisan literasinya dari dimensi proses, konten, dan konteks.

(2) Dari hasil validasi yang dilakukan oleh validator sangat layak dengan sedikit masukan. Begitu juga dengan aspek bahasa dan kegrafikan sangat layak dengan sedikit masukan tentang suara dan menambahkan alat teknologi untuk lebih menyempurnakan media pembelajaran komik digital berbasis STEM. (3) Respon siswa kelas VI SDN 2 Rejang Lebong dalam penggunaan media komik digital terdiri atas tiga aspek yaitu aspek materi, aspek bahasa, dan aspek kemenarikan. Dari ketiga aspek respon diperoleh hasil rata-rata respon 97,85\%, sehingga media komik digital berbasis STEM dikategorikan sangat praktis. Tes yang digunakan dalam pengembangan media hanya untuk mengetahui peningkatan pengetahuan siswa dimensi proses, konten, dan konteks. Dari hasil pretest dan posttest diperoleh peningkatan hasil tes. Secara berurutan dimensi proses lebih tinggi dari dimensi konteks, dan konten.

\section{Ucapan Terimakasih}

Trimakasih kepada semua pihak yang telah membantu peneliti sehingga bisa mendapatkan produk yang bermanfaat untuk pembelajaran. Terimakasih kepada kepala sekolah SDN 2 Rejang Lebong yang telah memberikan izin kepada peneliti untuk melakukan penelitian pengembangan ini.

\section{Daftar Referensi}

Abtahi, M., \& Battell, C. (2017). Integrate Social Justice Into the Mathematics Curriculum in Learning. Jurnal Ilmiah Peuradeun, 5(1), 101-114. doi:10.26811/peuradeun.v5i1.123

Arifin, Zainal. (2012). Penelitian Pendidikan: Metode dan Paradigma Baru. Bandung: PT. Remaja Rosdakarya.

Badarch, L., \& Zanabar, A. (2017). Dimensions of Hotel Service Quality in Mongolia. Jurnal Ilmiah Peuradeun, 5(2), 141-156. doi:10.26811/peuradeun.v5i2.130 
BSNP, (2011). Standar Kompetensi dan Kompetensi Standar sekolah Dasar/ Madrasah Ibtidaiyah (Lampiran 1 Peraturan Mendiknas No. 22 Tahun 2006). Jakarta: Kementrian Pendidikan Nasional.

Hariyanto, B. (2020). Pengembangan Aplikasi Anola Berbasis Android untuk Pembelajaran Atletik Nomor Lari Jarak Pendek. Jurnal Didaktika Pendidikan Dasar, 4(2), 515-536. https://doi.org/10.26811/didaktika.v4i2.150

Jalilehvand, M. (2012). The Effects of Text Length and Picture on Reading Comprehension of Iranian EFL Students. Asian Social Science, 8(3), 111-112.

Mardapi, Djemari. (2008). Teknik Penyusunan Instrumen Tes dan Non-Tes, Yogyakarta: Mitra Cendikia Press

Ninoersy, T., Tabrani, Z. A., \& Wathan, N. (2019). Manajemen Perencanaan Pembelajaran Bahasa Arab Berbasis Kurikulum 2013 pada SMAN 1 Aceh Barat. FITRAH: Jurnal Kajian Ilmu-ilmu Keislaman, 5(1), 83-102. doi: https://doi.org/10.24952/fitrah.v5i1.1759

Prasetyaningrum, E. W. (2020). Peningkatan Hasil Belajar Peserta Didik Konsep Pra Aksara Melalui Strategi Digital Pre-Historic Assesment. Jurnal Didaktika Pendidikan Dasar, 4(3), 655-676. https://doi.org/10.26811/didaktika.v4i3.128

Rahman, A.A. (2020). Pengembangan Media Pembelajaran Aquoponik-Induksi Elektromagnetik untuk Meningkatkan Literasi Sains Siswa Melalui Pembelajaran Berbasis STEM. Jurnal Didaktika Pendidikan Dasar. 4(2)

Saminan, S., Risa, N., \& Hamid, T. (2017). Implementation of ARIAS Learning Model Integrated With Constructivist Theory to Improve Student Learning Outcomes. Jurnal Ilmiah Peuradeun, 5(2), 213-224. doi:10.26811/ peuradeun.v5i2.124

Sugiyono. (2013). Metode Penelitian Kuantitatif, Kualitatif dan R\&D. Bandung: CV. Alfabeta.

Sugiyono. 2015. Metode Penelitian Pendidikan (Pendekatan Kuantitatif, Kualitatif dan R\&D). Bandung: CV. Alfabeta.

Sutrisno, R.R \& Hamdu, G. (2020). Aplikasi Mobile Learning Model Pembelajaran STEM Untuk Guru Sekolah Dasar. Jurnal Kajian Teknologi Pendidikan. 3(3).

Tabrani ZA. (2014). Dasar-Dasar Metodologi Penelitian Kualitatif. 
Yogyakarta: Darussalam Publishing.

Thiagarajan, Sivasailam, dkk. (1974). Instructional Development for Training Teachers of Exceptional Children. Washinton DC: National center for improvement educational system.

Walidin, W., Idris, S., \& Tabrani ZA. (2015). Metodologi Penelitian Kualitatif $\mathcal{E}$ Grounded Theory. Banda Aceh: FTK Ar-Raniry Press.

Yuliati, Y. (2017). Literasi Sains dalam Pembelajaran IPA. Jurnal Cakrawala Pendas, 3(2), 21-28.

Yusrizal, Y., \& Hanif, K. (2017). Increasing of Students' Motivation in Learning Physics Through the Use of Computer Simulation Media Viewed From Parents' Employment Background. Jurnal Ilmiah Peuradeun, 5(2), 201-212. doi:10.26811/peuradeun.v5i2.129 